\title{
PENGARUH ADMINISTRASI PENDIDIKAN,PENGAWASAN TERHADAP MUTU PROSES BELAJAR MENGAJAR DI RAUDHATUL ATFHAL (RA) KAB GOWA
}

\author{
Abdul. Rahman Abdi \\ avanmarta2@gmail.com \\ STIE NOBEL INDONESIA MAKASSAR
}

\begin{abstract}
Abstrak
Penelitian ini bertujuan 1) mengetahui dan menganalisis pengaruh parsial administrasi pendidikan, pengawasan terhadap proses belajar mengajar di RA 2) mengetahui dan menganalisis pengaruh simultan administrasi pendidikan dan pengawasan terhadap proses belajar mengajar di RA. Penilitian ini menggunakan instrumen pengumpul data berupa angket/kuisoner yang diberikan kepada guru-guru RA di kabupaten Gowa. Populasi sebanyak 76 guru sekaligus sampel dengan teknik sampel jenuh. Hasil uji hipotesis dengan analisa regresi liner berganda menunjukkan nilai $(-2,97>1,666)$ artinya kontribusi adminstrasi pendidikan secara parsial berpengaruh terhadap terhadap mutu proses belajar mengajar di RA. Pengaruh pengawasan terhadap mutu proses belajar mengajar di Raudhatul Atfhal ( RA ). Hasil menunjukkan kontribusi pengawasan secara parsial berpengaruh terhadap terhadap mutu proses belajar mengajar $(6,421>1,666)$. Pengaruhnya secara bersama-sama kedua variabel independen tersebut terhadap mutu proses belajar mengajar di Raudhatul Atfhal (RA) menjelaskan sebesar 61,0 percent memberikan pengaruh terhadap variable dependen yakni mutu proses belajar mengajar. Nilai signifikansi variabel bebas terhadap mutu proses belajar mengajar $(0,000<0,05)$ maka ada pengaruh secara signifikan variabel bebas terhadap mutu proses belajar mengajar di RA
\end{abstract}

Kata Kunci: Administrasi Pendidikan, Pengawasan, Mutu Proses Belajar Mengajar.

\begin{abstract}
This research to knowing and analyzing: 1) the influence partial of administration education and controlling on the quality of learning and teaching proces. 2) Effect of simultaneous adminstration education and controlling to the quality of learning an teaching proces in RA. This research used instrument data collectors in the form of questionnaires to all teachers RA Gowa regency. Population of 76 teachers at once sample. with using saturation sampling technique. The hypothesis test is multiple linear regression analysis the results showed $(-2,97>1,666)$ there are contribution adminstration education influence partial on the variable quality of laerning and teaching proces in RA. The results showed that there are contribution controlling influence partial on the variable quality of laerning and teaching proces $(6,421>1,666)$. Variable administration education and controlling simultaneously affect the quality of learning and teaching proces in RA explain 61,0 percent. Value significant independent variable on the variable quality of learning and teaching proces $(0,000<0,05)$ then there influence have a significant independent variable on the quality of learning and teaching proces in RA.
\end{abstract}

Keywords: Adminstration education, controlling, quality of learning and teaching proces 


\section{AkMen

\section{PENDAHULUAN}

Keberhasilan sebuah lembaga pendidikan sangat ditentukan oleh peran kepala sekolah sebagai pengelola pendidikan juga penataan administrasi pendidikan. Kepala sekolah sebagai pemimpin di lembaganya, maka kepala sekolah harus mampu membawa lembaga ke arah tercapainya tujuan yang telah di tentukan. Hal inilah yang mendorong lembaga/ sekolah selalu berusaha agar mutu pendidikannya lebih berkualitas dan dapat mengikuti perkembangan zaman guna mencetak lulusan yang handal, berkualitas, kreatif. mandiri

Proses belajar mengajar mengajar hakekatnya merupakan suatu proses penyampaian pesan dari sumber pesan melalui saluran atau media tertentu ke penerima pesan. Sumber pesannya bisa kepala sekolah, guru, siswa, ataupun orang tua. Salurannya adalah media pendidikan dan penerima pesannya adalah siswa atau juga guru.

Rivai, (2010) administrasi adalah keseluruhan proses yang mempergunakan dan mengikutsertakan semua sumber potensi yang tersedia dan yang sesuai, baik personel maupun materil dalam usaha untuk mencapai tujuan bersama seefektif dan seefisien mungkin.. Sopia,(2012) Administrasi pendidikan merupakan usaha kolektif dan kerjasama sekelompok orang didalam lembaga pendidikan berdasarkan ketentuan-ketentuan dan batasan-batasan kemampuan tertentu..

Kepala sekolah harus mampu melihat adanya perubahan terhadap regulasi pendidikan dan kehidupan globalisasi. Kepemimpinan kepala sekolah sangat menunjang akan tercapainya pengelolaan sekolah yang efektif dan efisien. Untuk menciptakan sekolah yang efektif dan efisien, kepala sekolah sebagai manajer pendidikan di tingkatan sekolah dan ujung tombak utama dalam mengelola administrasi pendidikan dan pengawasan diharapkan mampu memegang tugas dan bertanggung jawab memegang peran aktif dalam memajukan sekolah / lembaga pendidikan.

Danim (2011) Pengawas Sebagai konsultan yaitu pengawas harus memiliki kemampuan sebagai spesialis dalam masalah kurikulum, metodologi pembelajaran, dan pengembangan staf, sehingga pengawas dapat membantu guru baik secara individual maupun kelompok

Faktor penghambat tercapainya kualitas/mutu proses belajar mengajar di sekolah seperti adminstrasi tata laksana sekolah yang masih lemah, proses pengangkatan tenaga pengajar belum sesuai spesifikasi gelar kesarjaannya, tata kelola penilaian dan mutu pengukuran murid dan pengawasan kepala sekolah yang ditandai dengan kurangnya supervisi dalam melakukan tugas baik administrasi maupun mengajar para guru, dan seringnya guru maupun staf datang terlambat, wawasan dan pemahaman tentang administrasi pendidikan yang masih sempit, Ini mengimplikasikan rendahnya mutu proses belajar mengajar (input, proses, dan output).

Berdasarkan fenomena diatas dapat diketahui dari data sekolah dan guru RA yang berada di Kab Gowa adalah 76 guru dan 22 RA. Penulis tertarik untuk melakukan penelitian lebih mendalam dengan harapan dapat mengetahui sejauh mana administrasi pendidikan dan pengawasan kepala sekolah memberikan pengaruh terhadap mutu proses belajar mengajar. Maka lahirlah judul Pengaruh administrasi pendidikan dan pengawasan kepala sekolah terhadap mutu proses belajar mengajar di Raudhatul Atfhal (RA) Kabupaten Gowa”

Administrasi dapat menghubungkan antara proses pendidikan dan tujuan-tujuan pembangunan dalam masyarakat, serta mempererat hubungan pendidikan dengan masyarakat/lingkungan. (Sophia,2012) kegiatan kelompok kerja sama dalam pendidikan dan lingkungan masyarakat untuk mencapai tujuan-tujuan bersama. Administrasi pendidikan adalah proses social dengan arti kata bahwa administrasi pendidikan tersebut harus memberikan manfaat bagi masyarakat

Pengawasan merupakan upaya untuk membantu pembinaan dan peningkatan kemampuan pihak yang diawasi agar mereka dapat melaksanakan tugas kegiatan yang telah 
ditetapkan secara efisien dan efektif. Tugas pengawas pendidikan yaitu: menghadiri rapat/pertemuan, mendiskusikan tujuan-tujuan dan filsafat pendidikan dengan guru-guru, melakukan classroom visitation atau class visit, memilih dan menilai buku-buku yang diperlukan bagi murid-murid, membimbing guru-guru dalam menyusun dan mengembangkan sumber-sumber atau unit-unit pengajaran, memberikan saran-saran atau instruksi tentang bagaimana melaksanakan suatu unit pengajaran, mengorganisasi dan bekerja dengan kelompok guru-guru dalam program revisi kurikulum, menginterprestasikan data tes kepada guru-guru dan membantu mereka bagaimana menggunakannya bagi perbaikan pengajaran.

Makawimbang (2011) Mutu merupakan suatu hal yang sangat penting dalam kehidupan manusia baik secara individual, berkelompok, bermasyarakat, berbangsa dan bernegara, karena mutu adalah faktor yang mendasar pada peserta didik. Belajar merupakan suatu proses yang ditandai dengan adanya perubahan pada diri peserta didik

Karena itu seseorang dikatakan belajar bila dapat diasumsikan bahwa dalam diri orang itu terjadi suatu proses yang mengakibatkan suatu perubahan. Seseorang akan dikatakan belajar bila dalam diri orang itu terjadi suatu proses yang mengakibatkan suatu perubahan tingkah laku. Sardiman (2012) mengatakan bahwa mengajar adalah menyampaikan atau menanamkan pengetahuan kepada peserta didik dengan suatu harapan terjadi proses pemahaman. Mengajar adalah suatu kegiatan dimana pengajar menyampaikan pengetahuan atau pengalaman yang dimiliki kepada peserta didik. Proses belajar adalah segala pengalaman belajar yang dihayati oleh peserta didik. Makin intensif pengalaman yang dihayati oleh peserta didik makin tinggilah mutu proses belajar yang dimaksud. Tingkat partisipasi aktif peserta didik dalam proses belajar merupakan salah satu indikator proses belajar yang bermutu. Rasa keterlibatan yang dilandasi oleh motivasi dan minat yang tinggi dari pihak pelajar dalam mengikuti proses belajar dikelas merupakan indikator dari proses yang bermutu. Berdasarkan uraian diatas maka penelitian ini disusun dengan konsep kerangka pikir sebagaimana gambar berikut ini:

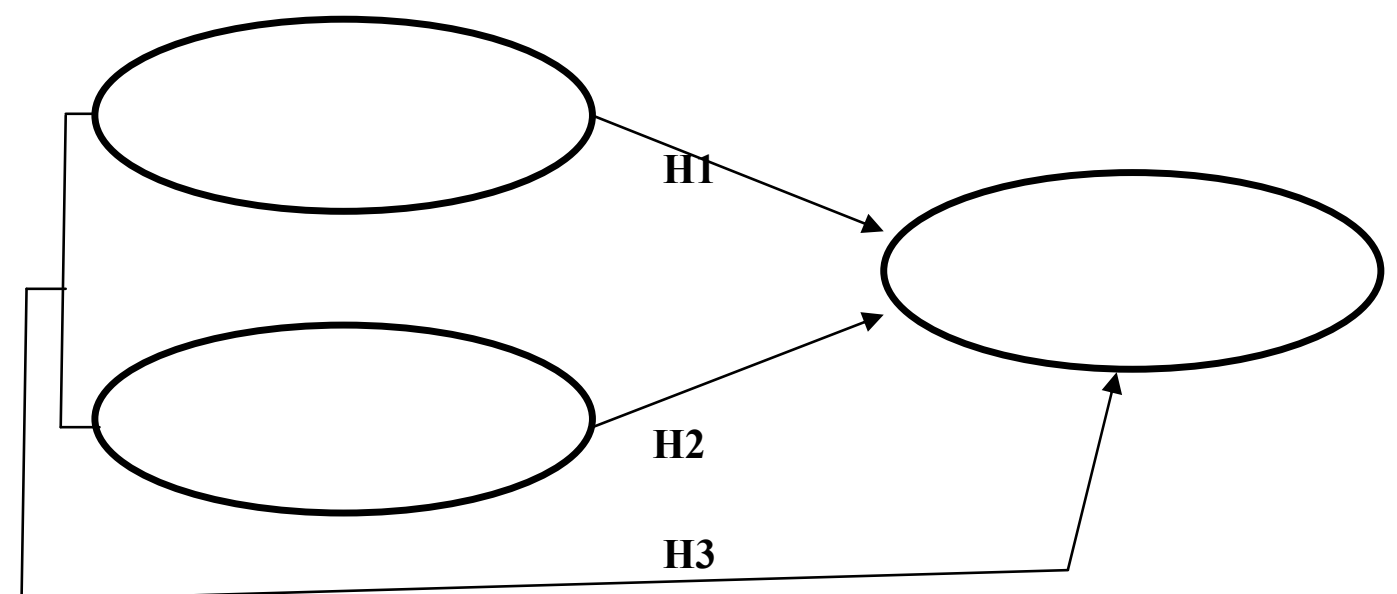

Merujuk gambar kerangka pemikiran di atas maka dapat dibuatkan hipotesis untuk kemudian kembangkan dalam penelitian ini yaitu

1. Adminstrasi pendidikan, Pengawasan Kepala Sekolah, berpengaruh secara parsial tehadap mutu proses belajar mengajar di RA

2. Adminstrasi pendidikan, Pengawasan Kepala Sekolah berpengaruh secara simultan terhadap mutu proses belajar mengajar di RA 
Pendekatan penelitian yang digunakan dalam penelitian ini adalah metode kuantitatif dengan pendekatan eksplanatori, yakni suatu metode penelitian yang menggunakan perspektif pendekatan kuantitatif yang akan digunakan untuk menjelaskan apakah ada pengaruhnya administrasi pendidikan dan pengawasan kepala sekolah terhadap mutu proses belajar mengajar dan penelitian deskriptif yaitu penelitian yang berusaha untuk mengutarakan pemecahan suatu permasalahan yang terjadi saat ini berdasarkan data-data dan bertujuan untuk memecahkan permasalahan tersebut secara sistematis dan factual mengenai fakta-fakta yang ada dan sifat dari populasi tersebut. Pengumpulan data dapat dilakukan pada obyek yang diharapkan dapat memberikan informasi atau data yang dibutuhkan. Populasi dalam penelitian ini yakni jumlah keseluruhan guru RA di Kabupaten Gowa sebanyak 76 orang. Berdasar pada pemahaman tentang sampel dan sesuai populasi yang ada maka sampel yang paling sesuai dengan populasi yang dimiliki peneliti adalah sampel jenuh dimana keseluruhan populasi dijadikan sebagai sampel sebanyak 76 guru. Jenis data adalah data kualitatif yaitu data penelitian yang bukan angka, yang sifatnya tidak dapat dihitung berupa informasi atau penjelasan yang didasarkan pada pendekatan teoritis dan penilaian logis. Data kuantitatif yaitu data yang berbentuk angka yang sifatnya dapat dihitung dan diukur jumlahnya untuk diolah menggunakan metode statistik. Sumber data terdiri dari Data primer merupakan data penelitian yang diperoleh secara langsung dari sumber asli ( tidak melalui media perantara ). Data primer yang digunakan dalam penelitian ini data yang diperoleh secara langsung dari hasil responden atas kuesioner (daftar pertanyaan) yang disebarkan kepada guru-guru yang menjadi sampel dalam penelitian ini. Data sekunder adalah data penelitian yang diperoleh secara tidak langsung melalui media perantara (diperoleh dan dicatat oleh pihak lain).

\section{HASIL PENELITIAN DAN PEMBAHASAN}

\section{Deskripsi Hasil Penelitian}

Berdasarkan analisis statistik dalam melihat pengaruh parsial dengan menggunakan uji regresi linier berganda untuk penelitian ini, maka didapatkan hasil sesuai oleh data dengan menggunakan bantuan aplikasi program komputer SPSS (Statistical Product and Service Solutions) for Windows versi 19

Tabel. Coefficients/Koefisien Regresi ( B )

\begin{tabular}{|c|c|c|c|c|c|c|c|c|c|}
\hline \multicolumn{10}{|c|}{ Coefficients ${ }^{A}$} \\
\hline \multirow[b]{2}{*}{ Model } & & \multicolumn{2}{|c|}{ Unstandardized Coefficients } & \multirow{2}{*}{$\begin{array}{c}\begin{array}{c}\text { Standardized } \\
\text { Coefficients }\end{array} \\
\text { Beta }\end{array}$} & \multirow[b]{2}{*}{$\mathrm{t}$} & \multirow[b]{2}{*}{ Sig. } & \multicolumn{3}{|c|}{ Correlations } \\
\hline & & B & Std. Error & & & & Zero-order & Partial & Part \\
\hline \multirow[t]{3}{*}{1} & (Constant) & 3,245 & 2,572 & & 1,262 & .211 & & & \\
\hline & Admin Pendidikan & -.014 &, 046 & -.029 & -.297 & .768 & 138 & -035 & -027 \\
\hline & Pengamasan & 462 & .072 & 618 & 0,421 & .000 & 610 & 601 & 595 \\
\hline
\end{tabular}

a. Dependent Variable: Mutu PEM

Sumber data: Data primer diolah SPSS versi 19

Dari model persamaan regresi yang dapat dijelaskan hasil olah data out data sebagai berikut :

$$
\mathrm{Y}=3,245+-0,014 \mathrm{X} 1+0,462 \mathrm{X} 2
$$

Persamaan regresi tersebut dapat dejelaskan sebagai berikut: 
a. Konstanta sebesar 3,245: artinya jika administrasi pendidikan, dan pengawasan nilainya 0 , maka mutu proses belajar mengajar di RA nilainya sebesar 3,245

b. Koefisien regresi variabel administrasi pendidikan sebesar $-0,014$ : artinya jika variabel administrasi pendidikan mengalami kenaikan satu satuan, maka mutu proses belajar mengajar akan mengalami penurunan sebesar -0,014 satuan dengan asumsi variabel independen lainnya bernilai tetap. Ini berarti semakin diperketat pelaporan administrasi pendidikan akan mengalami penurunan mengajar di kelas karena waktu yang dipakai untuk mengajar tersita atau diambil untuk membuat laporan administrasi pendidikan.

c. Koefisien regresi variabel pengawasan kepala sekolah sebesar 0,462 : artinya jika pengawasan kepala sekolah mengalami kenaikan satu satuan, maka mutu proses belajar mengajar akan mengalami peningkatan sebesar 0,462 satuan dengan asumsi variabel independen lainnya bernilai tetap. Ini berarti semakin di tingkatkan pengawasan melalui supervisi pengajaran dan pelaksanaan kurikulum di kelas akan meningkatkan mutu proses belajar mengajar di RA

\section{Pengujian hipotesis Uji t}

Untuk pengujian hipotesis menggunakan bantuan software computer program SPSS versi 19.00. Sebelum melakukan pengujian hipotesis, maka terlebih dahulu ditentukan derajat signifikannya atau tingkat kesalahan data yang diinginkan. Derajat signifikan yang diharapkan dalam penelitian ini adalah sebesar, $\alpha$ (alfa) $=0,05$. Ini berarti tingkat kebenaran data diinginkan adalah sebesar 95\%. Kriteria pengujian hipotesis kerja yaitu: Ho diterima dan $\mathrm{H} 1$ ditolak apabila $-\mathrm{t}$ tabel $\leq \mathrm{t}$ hitung $<\mathrm{t}$ table, dengan derajat kebebasan df (n-k-1) ( $\mathrm{n}=$ jumlah data, $\mathrm{k}=\mathrm{jumlah}$ variabel bebas) artinya tidak mempunyai pengaruh antara variable independen dan dependen. Sebaliknya Ho ditolak dan H1 diterima apabila $t$ hitung $>t$ table, artinya mempunyai makna ada pengaruh.

\section{Administrasi Pendidikan}

Nilai $t$ hitung $>$ tabel $(-2,97>1,666)$ maka Ho ditolak, artinya bahwa adminstrasi pendidikan (X1) secara parsial berpengaruh terhadap terhadap mutu proses belajar mengajar di RA kabupaten Gowa. Nilai t hitung negatif, artinya semakin tinggi baik administrasi pendidikan maka mutu proses belajar mengajar di RA tidak semakin meningkat atau bagus

\section{Pengawasan Kepala Sekolah}

Karena nilai $\mathrm{t}$ hitung $>\mathrm{t}$ tabel $(6,421>1,666)$ maka Ho ditolak, artinya bahwa pengawasan (X2) secara parsial berpengaruh terhadap terhadap mutu proses belajar mengajar di RA kabupaten Gowa. Nilai t hitung positif, artinya pengaruh yang terjadi adalah positif, berarti semakin tinggi atau baik pengawasan (X2) maka mutu proses belajar mengajar di RA semakin meningkat atau bagus.

\section{Pengujian hipotesis Uji F}

Uji F digunakan untuk menguji pengaruh variabel bebas (administrasi pendidikan dan pengawasan) secara bersama-sama terhadap variabel tergantung (mutu proses belajar mengajar) di RA

\section{Tabel.Uji Koefisien Regresi Dengan Uji F Hitung}




\section{ANOWA}

\begin{tabular}{|c|c|c|c|c|c|c|}
\hline \multicolumn{2}{|c|}{ Model } & $\begin{array}{l}\text { Surrof of } \\
\text { Squares }\end{array}$ & $d f$ & Mean Square & $F$ & Sig. \\
\hline \multirow[t]{3}{*}{1} & Regression' & 125,479 & 2 & 62,740 & 21,719 & $0000^{\mathrm{a}}$ \\
\hline & Residual & 210,876 & 73 & 2,800 & & \\
\hline & Total & 336355 & 75 & & & \\
\hline
\end{tabular}

a. Fredictors: (Constanti), Pengawasan, Adrrin Pendidikan

b. Dependent Variable: Mutu FEM

Karena nilai $\mathrm{F}$ hitung $>\mathrm{F}$ tabel $(21,719>3,122)$ maka Ho ditolak, artinya bahwa Administrasi pendidikan dan pengawasan secara bersama- sama berpengaruh terhadap mutu proses belajar mengajar di RA kabupaten Gowa. Apabila hasil perhitungan memperlihatkan adanya pengaruh antara variable independen dengan variable dependen, maka untuk mengukur tingkat pengaruh secara simultannya diantara variable yang diteliti maka peneliti menggunakan uji $\mathrm{F}$ dengan tingkat keyakinan 95\%, $\alpha$ (alfa) sebesar 0,05 atau 5\%, df 1 ( jumlah variabel -1$)$ atau $3-1=2$ dan df $2(n-k-1)$ kriteria pengujianya adalah $\mathrm{H} 0$ diterima apabila $\mathrm{F}$ hitung $\leq \mathrm{F}$ tabel, $\mathrm{H} 0$ ditolak apabila $\mathrm{F}$ hitung $>\mathrm{F}$ tabel. Jika H0 ditolak artinya variabel independen secara bersama-sama berpengaruh terhadap variabel dependen.

Tabel. Analisis Determinasi Pengaruh Administrasi Pendidikan dan Pengawasan Terhadap Mutu Proses Belajar Mengajar

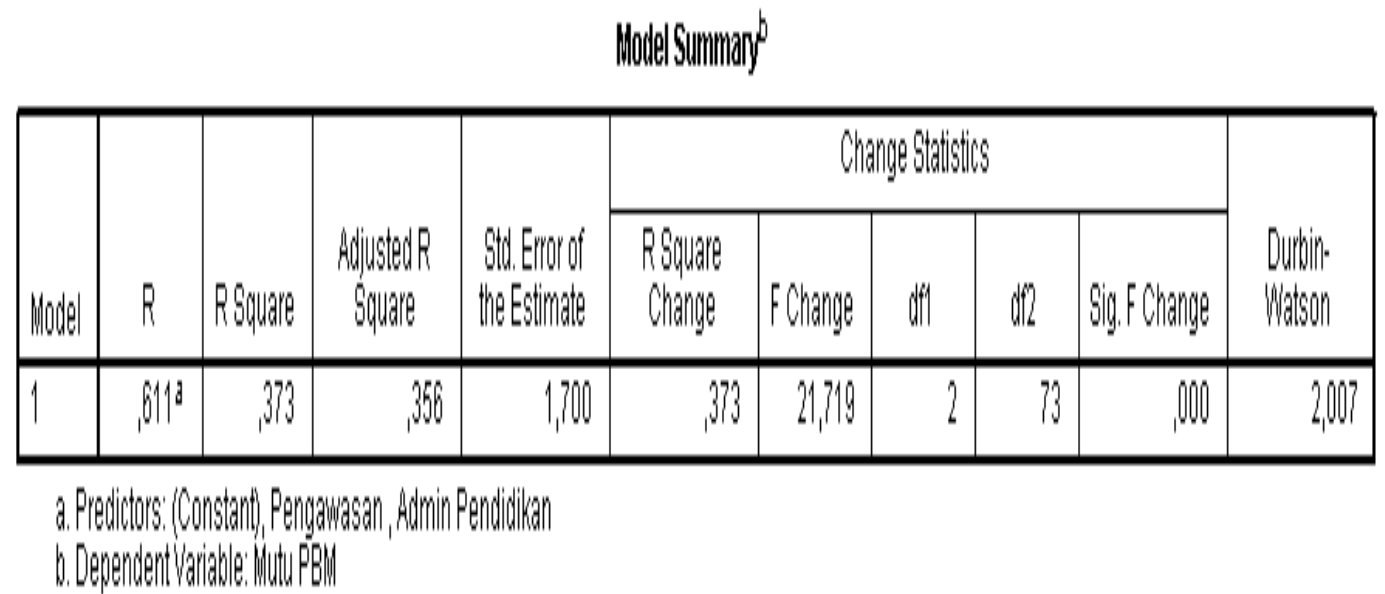

Analisis determinasi digunakan untuk mengetahui prosentase sumbangan pengaruh variabel independen terhadap variabel dependen. Hasil analisis determinasi dapat dilihat pada output Moddel Summary dari hasil analisis regresi linier berganda diatas. R sebesar 0,611 atau $(0,611 \times 100=61,0 \%)$. Hal ini menunjukkan bahwa model mampu menjelaskan sebesar $61,0 \%$ pengaruhnya terhadap variasi variable dependen. Sedangkan sisanya sebesar $39 \%$ dipengaruhi oleh variabel lain yang tidak dimasukkan dalam model penelitian ini.

\section{Pembahasan Hasil Penelitian}


Hasil penelitian ini menunjukkan variabel independent yaitu administrasi pendidikan, pengawasan kepala sekolah berpengaruh secara positif unruk pengawasan dan berpengaruh negatif untuk administrasi pendidikan serta signifikan terhadap Mutu Proses Belajar Mengajar. Menurut Sophia (2012) Administrasi pendidikan merupakan proses kemanusiaan yang bertujuan agar terpenuhi keinginan dan kebutuhan manusia dalam rangka memperbaiki kehiduan manusia melalui perubahan manusia yang bersangkutan. administrasi pendidikan merupakan kekuatan penting dalam pengajaran yang lebih baik bagi seluruh anak-anak didalam organisasi sekolah untuk mencapai tujuan dan menjamin pencapaian mutu.

Penelitian dilakukan sejalan dan saling mendukung dengan penelitian yang dilakukan oleh peneliti sebelumnya salah satunya Regina "Pengaruh pengawasan kepala sekolah dalam meningkatkan kualitas belajar siswa". Penelitian ini bersifat deskriptif. Yang menjadi subyek subyek penelitian adalah guru-guru. Hasil yang diperoleh dari penelitian ini adalah pengawasan kepala sekolah dapat meningkatkan kualitas belajar siswa sekaligus menjadi pendorong dalam peningkatan kualitas belajar siswa. Wahyudi pengaruh administrasi pendidikan dan dan motivasi berprestasi terhadap kepuasan kerja guru. Penelitian ini menggunakan pendekatan kuantitatif dengan teknik korelasional. Data diperoleh dengan pengumpulan data yang dilakukan dengan angket dan hasil analisis korelasi dan regresi ganda ditemukan bahwa terdapat korelasi positif dan signifikan antara administrasi pendidikan terhadap kepuasan kerja guru dengan nilai 33,0\%, terdpat korelasi positif dan signifikan antara motivasi terhadap kepuasaan kerja guru dengan nilai 63,4\%, dan terdapat korelasi positif dan signifikan antara administrasi pendidikan dan motivasi secara bersama-sama terhadap kepuasan kerja guru dengan nilai $94,5 \%$.

\section{KESIMPULAN}

Dari hasil pengujian hipotesis dan pembahasan hasil penelitian, maka penulis mengambil kesimpulan sebagai berikut:

1. Analisis determinasi menunjukkan bahwa prosentase sumbangan pengaruh variabel independen yaitu administrasi pendidikan dengan indikator adminstrasi murid, tata laksana sekolah, pendidik dan tenaga kependidikan terhadap variabel mutu proses belajar mengajar di Raudhatul Atfhal ( RA ) kabupaten Gowa sebesar 86,0\%. Dan signifikan berdasarkan pada output diperoleh nilai signifikansi output lebih kecil dari signifikansi $0,05(0,023<0,05)$ maka Ho ditolak sehingga peneliti menyimpulkan bahwa dari nilai output tersebut menunjukkan ada pengaruh secara signifikan variabel administrasi pendidikan terhadap mutu proses belajar mengajar di RA Kabupaten Gowa.

2. Prosentase sumbangan pengaruh variabel independen yaitu pengawasan dengan indikator pelaksanaan kurikulum dan supervisi pengajaran terhadap variabel mutu proses belajar mengajar di Raudhatul Atfhal ( RA ) kabupaten Gowa. Atau variasi variabel bebas yang digunakan dalam model mampu menjelaskan sebesar 55,0\% pengaruhnya terhadap variasi variable dependen. Nilai signifikan pada output diperoleh nilai signifikansi output lebih kecil dari signifikansi $0,05(0,000<0,05)$ maka Ho ditolak sehingga peneliti menyimpulkan bahwa dari nilai output tersebut menunjukkan ada pengaruh secara signifikan variabel pengawasan terhadap mutu proses belajar mengajar di RA Kabupaten Gowa. 
3. Prosentase sumbangan pengaruhnya secara bersama-sama kedua variabel independen atau variabel bebas yang digunakan dalam model mampu menjelaskan sebesar $61,0 \%$ pengaruhnya terhadap variable terikat.Signifikansi berdasarkan pada output diperoleh nilai signifikan output lebih kecil dari signifikansi $0,05(0,000<0,05)$ maka Ho ditolak sehingga peneliti simpulkan bahwa dari nilai output tersebut menunjukkan ada pengaruh secara signifikan kedua variabel bebas terhadap mutu proses belajar mengajar di RA Kabupaten Gowa

\section{SARAN}

Berdasarkan kesimpulan dan implikasi penelitian yang telah dikemukakan sebelumnya, maka penulis ajukan beberapa saran sebagai berikut:

1. Kegiatan adminstrasi pendidikan dan pengawasan kepala sekolah lebih pada pengarahan yang model inovatif, pembimbingan pada guru-guru sehingga lahir beberapa terobosan baru yang berdampak pada peningkatan mutu proses belajar mengajar

2. Agar dilakukan penelitian lanjutan dengan kajian lebih luas dan menambah variabel yang belum diteliti secara konseptual dan inferensial berpengaruh terhadap mutu proses belajar mengajar.

\section{DAFTAR PUSTAKA}

Danim, Sudarman. 2011. Profesi Kependidikan. Bandung: CV. Alfabeta

http://sopiatunnawiyah.blogspot.com/2012/10/makalah-administrasi-pendidikan. Html diakses tanggal 18 januari 2016 pukul 22.26 .

Makawimbang, Jerry H.2011. Supervisi Dan Peningkatan Mutu Pendidikan. Bandung: Alfabeta.

Rivai, A, Sudjana, N 2010 Media Pengajaran. Bandung: Sinar Baru Algesindo.

Sardiman, 1992. Interaksi Dan Motivasi Belajar Mengajar. Rajawali Press, Jakarta

Sardiman A.M, 2012 Motivasi Belajar Mengajar. Jakarta: PT Raja Grafindo Persada.

Sutawidjaja, Akbar,1991. Penggunan Alat Peraga Dalam Pengajaran Matematika Disekolah Dasar, Penataran Penyiapan Penatar Dosen PGSD-D II Guru Kelas, Jakarta

Soedijarto, Dkk. 1991. Mencari Strategi Pengembangan Pendidikan Nasional Menjelang Abad XXI. PT Grasindo, Jakarta.

Sugiyono, 2017. Metode Penelitian Bisnis, CV. Alfabeta, Bandung 2013, Metode Penelitian Administrasi, CV. Alfabeta, Bandung 